\title{
Open Marxism and critical theory: negative critique and class as critical concept
}

Christos Memos

This is the Accepted Manuscript of the book chapter:

Memos, C. 2018. Open Marxism and critical theory: negative critique and class as critical concept. In: B. Best, W. Bonefeld \& C. O'Kane (eds.). The SAGE handbook of Frankfurt school critical theory. London: SAGE, pp. 1314-1331.

It has been published in final form at doi: http://dx.doi.org/ 10.4135/9781526436122.n80 
Memos, Christos (2018) 'Open Marxism and Critical Theory: Negative Critique and Class as Critical Concept', in Beverley Best, Werner Bonefeld, Chris O'Kane, Neil Larsen (eds.) Handbook of Frankfurt School Critical Theory - A three-volume set to be published by Sage.

\title{
OPEN MARXISM AND CRITICAL THEORY: NEGATIVE CRITIQUE AND CLASS AS CRITICAL CONCEPT
}

\author{
Christos Memos
}

Abertay University, Dundee

\begin{abstract}
'Revolutionary transformation has a tradition that must continue' (Horkheimer, 2007:104)

'Dialectics opens concepts. It focuses on social contents and does so by moving within their social forms. It is tasked with subverting the economic categories by revealing their social basis' (Bonefeld, 2014: 68)
\end{abstract}

\section{INTRODUCTION}

"Every age", according to Walter Benjamin, "must strive anew to wrest tradition away from the conformism that is working to overpower it" (1969: 255). In this astute observation, Benjamin opposes any kind of falsification and forgetting of the struggles against exploitation and repression. He emphasises the dangers of dogmatism, orthodoxy and conformism that, have repeatedly stifled the advancement of radical and emancipatory movements and, by extension, the interests of the oppressed. He lays the groundwork for a subversive thought that seeks to draw a line of demarcation between critical social theory and the survival of positivism - of whichever variety. Benjamin`s perspective succeeds in encapsulating the work of the early Frankfurt school that has provided the anti-capitalist movement with valuable resources upon which to draw in the fight against positivism. Rejecting the appearance of social and economic relations as supposedly natural phenomena, they were critical of any naturalization of society, and adamant in their denunciation of evolutionary 
conceptions of history and the philosophy of progress. Critical theory's conceptualization of society aimed to reveal the social world as the product of sensuous human activities. In doing so, its critical intention was not to attempt to humanise inhuman conditions, but to abolish social injustice with the aim of creating a society of the free and equal. However, during the complex progression of the twentieth century, reason often became "a poor ally of reaction" (Horkheimer, 1972: 271). Reason was "forced to live in the shadows" (Agnoli, 2003: 28), thereby renouncing its purpose to undertake incorruptible criticism and to fight barbarism in all its varieties. In other instances, as Agnoli (2003: 29-30) noted, with a biting irony, love prevailed: love for global justice, love for freedom and the democracy of the markets, love for the rights of man, for constitutional patriotism, communicative action, systems and lifeworlds. In other examples, love was expressed for party loyalty, for workers' parties and their leaders, for unconditional discipline, subordination to the party line and to ideological monolithism. In contradistinction to this affirmative, constructive love, the early and radical Octavio Paz, in his Piedra de Sol (Sunstone), supplies us with a different, subversive meaning of love: "to love is to battle, to open doors, to cease to be a ghost with a number forever in chains, forever condemned by a faceless master" (1991: 37). To love means to fight, refusing to "turn the mill that squeezes out the juice of life, that turns eternity into empty hours, minutes into prisons, and time into copper coins and abstract shit” (1991: 39).

This chapter argues that in the ongoing battles to unlock doors and open up concepts and fissures, with a view to opening up history itself in order to pave the way forward for class struggle, the Open Marxist tradition continues to advance the critical purpose of the early Frankfurt school, and of critical theory, in the direction of critical confrontation with traditional theory and positivism. Maintaining a critical strand, that originally manifested as critique of traditional theory, and of the prevailing positivism and scientificism in the Marxist tradition of the second and third internationals, Open Marxism constitutes the most recently renewed attempt to critique mechanistic interpretations of Marxism and any form of evolutionism, as well as naturalised conceptualisations of history and society. More precisely, the chapter focuses on the ways in which the Open Marxist tradition carries forward critical theory, with regards to negative critique and the critique of political economy as critical social theory. Through a consideration of "exposition, interpretation and contextualisation" (Clarke, 1994: 12), this chapter follows the development of Open Marxism: from Axelos's original and critical use of the term in the 1950s, to Agnoli's work of the 1980s, to the work of Clarke, Bonefeld, Gunn and Holloway - developed within the framework of the 
Conference of Socialist Economists (CSE) — since the 1990s. It will argue that the development of the Open Marxist tradition has to be understood as a process of interaction with socio-historical reality. Taking into account the complex history of the Open Marxism tradition, and the changes to the meaning of "Open Marxism" that occurred over time, it argues, in line with Schmidt, that "historical process is constitutive for the theoretical process and modifies its categories" (1981: 70). The second section argues that what makes Open Marxism specific, and constitutes common ground throughout its development phases, is its use of critique as a negative and destructive critique. This section scrutinises the notion of critique, establishes connections, and identifies key differences in the thought of the members of this particular Marxist tradition. Finally, the chapter focuses on the elaboration of the critique of political economy as critical social theory seen in the CSE Open Marxist school, and discusses that school's conception of social practice as a critique of the notion of class.

\section{MARXIAN THEORY AS AN OPEN-ENDED PROJECT}

The close of the Second World War signalled a period of intense intellectual ferment in France. Liberal political institutions were heavily undermined and strongly criticized, and past intellectual traditions, such as "analytical rationalism", were challenged and forcefully disputed. The establishment of German military authority in 1940 and the role played by the resistance movements during the years of German occupation led to a turn in intellectual discourse towards the critical philosophical tradition, whose conceptual framework was regarded as a highly suitable tool for the undertaking of in-depth analysis of the events and preoccupations of the time. In this context, a renewal of interest in Hegel's work, in particular, and primarily, in The Phenomenology of Spirit, and in the radical interpretation of that work as supplied by Kojeve and Hyppolite, occurred alongside a growth of interest in Marx's early writings, and especially in his Economic and Philosophical Manuscripts of 1844. Additionally, Husserl and Heidegger were brought into the emerging critical dialogue, or, were read in conjunction with Marx's Paris manuscripts. Hence the French intellectual landscape witnessed the emergence of a variety of philosophical strands, such as Hegelian Marxism, Heideggerian Marxism, Freudo-Marxism, Phenomenological Marxism and Existentialism. Opposed to the economism of the Second and Third Internationals, these schools of thought sought to locate the philosophical content of Marxism at the epicentre of their endeavour to renew Marxian theory and overcome its limitations and shortcomings. Nonetheless, despite the flourishing of these disparate versions of Marxism, each of which 
claimed to provide a non-dogmatic reading of Marx's work, the ideological power that the orthodox Marxism of the French Communist Party exerted over French political and intellectual developments remained powerful and dominant. Under these circumstances, and leaving Jean-Paul Sartre and the journal Les Temps Modernes aside, the journals Arguments, Socialisme ou Barbarie and Internationale Situationniste created a public forum for the critique of dogmatism and orthodox Marxism and functioned as a laboratory for the development of critical and radical ideas.

More specifically, the journal Arguments, which began publishing in 1956 and folded in 1962, developed into a critical space for theoretical debate that sought to transcend the sectarianism of the Left and strove towards an "opening up of Marxism towards new intellectual currents and new social phenomena" (Poster, 1975:212). Arguments was edited principally by scholars who attempted to simultaneously remain affiliated to the Left, being mostly ex-communists, and to maintain a critical perspective, whilst also adopting a critical distance from the Cold War period's anti-communist hysteria. Arguments brought together, as editors or contributing authors, intellectuals - such as Edgar Morin, Jean Duvignaud, Pierre Fougeyrollas, Maurice Blanchot, Deleuze, Roland Barthes, François Fejtö, Henri Lefebvre and Kostas Axelos-who sought to think beyond "orthodox Marxism" and to formulate counterarguments to the ideological use of Marx. Axelos joined the editorial board of Arguments in 1958, and from 1960-1962 acted as its editor-in-chief. He conceived of Arguments as a collective project, with the goal of elaborating an "open Marxism, of a revised and corrected Freudo-Marxism and finally, a post-Marxism and post-Heideggerian thought" (Elden, 2005:27) and he emphatically stressed that Marx is not "an orthodox Marxist" (Axelos, 1976: 302). Contradicting Althusser, Axelos emphasised that Marx's thought, which evolved in stages, must be seen as a unitary process, as "there are not two Marxes, the early and the late, the youthful and the mature", but rather, "two periods integrally bound together" (Axelos, 1976:45). In his view, "one cannot propose a onedimensional approach and reading of Marx. If someone did so, she would be dogmatic" (Memos, 2009: 134). Nonetheless, Axelos's analysis of Marx's thought, and in particular his exposition and interpretation of Marx's concept of alienation, is almost exclusively concerned with Marx's early writings, and principally with the Economic and Philosophical Manuscripts of 1844- he pays far less attention to the study of Capital. Axelos grounded his interpretation of Marx in the Paris Manuscripts of 1844, since they contain the "central point" of Marxian thought, retaining a "place of absolute centrality" and being "richest in ideas of 
all Marxian and Marxist writings" (1976: 46, 45). Axelos's adoption of this approach is rooted in his opinion that transcending the deformation of Marxism necessitated an opening up of Marxist thought, and he coined the term “Open Marxism” (Axelos, 1957). In Axelos's own words:

\footnotetext{
By using the term 'Open Marxism', I meant a theoretical current-which never came into being as a movement - and which, in opposition to Marxism-Leninism-Stalinism-Maoism, did not render Marxism an ideology of power, but attempted to pose fruitful questions and demystify the so-called 'existing realizations'. Lukács and Korsch made an effort, but their contemplative measures were limited. Any kind of action, political or non-political, cannot be defined a priori. (Memos, 2009: 133)
}

The core of Axelos's approach stemmed from his position that 'more than science, it is technique that affects Marx's enterprise' (1976:19). Marx's technicism constituted a significant part of what can be called the dogmatic element in his thought, and led to the forestalling of many lines of critical thought. It also made possible the reification of Marx's thinking and the development of orthodox and closed Marxism. Closed Marxism took on various forms, including sects of Marxist-Leninist, Stalinist and Trotskyist persuasions and the established ideology of bureaucratic regimes, all of which promoted the technicist elements of Marx's work. In consequence, technicism became dominant in both the theory and historical realization of orthodox Marxism, and the sectarian "-isms" prevailed, thereby transforming Marxian thought into systematized theory and reactionary dogma. Axelos`s undertaking to overcome the metamorphosis and closure of Marxism entailed the deployment of a mode of thinking that sought to broaden horizons and to render Marx as more problematic a thinker than is actually the case. This is a discourse that foregrounds questioning thought and complex enigmatic responses. Drawing upon Heraclitus' poetic thought, Axelos's Open Marxism is principally articulated as a project that seeks to open up Marx's more original and creative thinking (e.g. the concept of alienation) by entering it into a productive dialogue with other thinkers, including Hegel, Nietzsche and Heidegger (Axelos, 1966), with the aim of bringing it back to a "much more basic wandering" (Axelos, 1970:107). Axelos paid particular attention to reading Marx in conjunction with Heidegger, since, despite the considerable incompatibilities in their respective work, Axelos was impressed by what he perceived to be a "concurrent affinity-between what Marx calls alienation and Heidegger oblivion of Being" (Memos, 2009: 135). Therefore, in his work on Marx and Heidegger, Axelos sought to elaborate a future thought, one that could think through them and eventually "beyond them" (Axelos, 2015b: 37). 
In the late 1960s, renewed interest in radical politics and the resurgence of social, anticapitalistic and anti-authoritarian movements facilitated the revival, and continuation of, the legacy of critical Marxism and the Frankfurt School`s discursive traditions. In Germany, this renewal found expression, in part, in the re-assessment, and further development of, Marx's critique of political economy by the "new reading of Marx"-as instigated by Alfred Schmidt, Hans-Georg Backhaus and Helmut Reichelt—or, as a supplemental strand of the critique of political economy, and critique of the political, and of the state, undertaken primarily by Johannes Agnoli. In his influential Die Transformation der Demokratie (The Transformation of Democracy) in 1967, as well as in his other critiques of politics, Agnoli interrogated the transformation of "parliamentary democracy" into a representational mode of political power and domination, and supplied us with a profound critique of the form of the capitalist state. In contrast to Axelos, Agnoli's devastating assessment of "constitutional oligarchy" and parliamentarism (Agnoli, 2012a: 208) resulted not from situating Marx's work in a "productive dialogue" with Nietzsche or Heidegger-but rather, his critique of the transformation of democracy and the institutionalization of a radical opposition derived from his "productive dialogue" with Left communism, anarcho-syndicalism and revolutionary syndicalism (Agnoli, 2012b: 153). In his debate with Ernest Mandel with regard to the meaning of Marx's “critique" (Agnoli, 1980), and against the background of Althusser, in 1977, publically announcing a crisis in Marxism — which sparked impassioned debates in France and Italy-Agnoli employed the term "Open Marxism" in an attempt to distinguish his own critical reading, and use of Marxian thought, from that of "Orthodox Marxism" (1980: 7). For Agnoli, Marx is concerned primarily with the categories of "critique and destruction" (1980: 148) and his critical project of social emancipation amounted in no sense to a Weltanschauung (worldview). By underscoring the unity of theory and practice, Agnoli's Open Marxism indicates that concepts and categories remain open and incomplete in that the "heresy of reality" and the unpredictability of class struggle question the validity of the meaning of concepts. (Agnoli, 1980: 9, 148 and Bonefeld, 1992a: 84). History is not construed according to pre-established concepts and norms; it is, rather, the case that, as Open Marxism argues, critique connects conceptualisation and unpredictability, opens theory up to the practice of definite social relations, and opens up practice to theory (Bonefeld, 1992a: 85).

A few years later, in 1991, the demise of the USSR and the disintegration of soviet Marxism denigrated all the existing versions of "closed" and traditional Marxism. This was not simply 
another crisis of Marxism, of a sort that put into question its validity - the "end of history" was announced, and the triumph of the global-market society was seen as eliminating any alternatives to capitalism. Against a backdrop of necrology, renunciation of radical praxis and ideas, withdrawal and pervasive pseudo-consensus, eventually - as a consequence of the deep dissatisfaction with disintegrating Marxist orthodoxies and dogmas - a resurgence of strong interest in critical, open forms of Marxism came about. Traditional versions of Marxism were severely criticized and the historical tendency to uphold the party and the state as means of emancipation, and instruments of revolution, was discredited and rejected. In Britain, and specifically within the work of the members of the Conference of Socialist Economists (CSE), this process of reassessment fostered the development of a critical strand that owed much to a critical Marxist tradition elaborated, inter alia, by Luxemburg, the early Lukács, Korsch, Pannekoek, Rubin, Pashukanis, the early Frankfurt School, Rosdolsky, Johannes Agnoli and the tradition of 'autonomist' Marxism (Bonefeld et al., 1992b: xii). This discursive development crystallized, in the form of the work of a group of critical theorists, under the rubric of "Open Marxism" who included, amongst others, Simon Clarke, Werner Bonefeld, Richard Gunn and John Holloway. As distinct from Axelos's understanding of the term "Open Marxism", openness in this context referred to the "openness of Marxist categories themselves" (Bonefeld et al., 1992b: xi). That was an "openness on to practice" and had as its initial assumption "the class antagonism between capital and labour" (Bonefeld et al., 1992c: xi). This openness to the unpredictable, antagonistic character of social reality underlined the Open Marxism's acceptance of the inevitable incompleteness of concepts and categories. Contrary to the traditional Marxist separation of theory and practice, and its reproduction of the dualism between subject and structure, Open Marxism holds that object and subject, objectified structures and class struggles subsist in, and through, an internal relation. This entails that class struggle is viewed as "the movement of the contradiction in which capital, itself, consists" (1992c: xii) and the concept of class is grasped "not as a matter of grouping individuals, but as a contradictory and antagonistic social relation" (1992c: xiii).

Open Marxism does not propose a complete, definitive interpretation of Marx-it aims, rather, to open up a space for a theoretical and practical critique that seeks to pave the way forward, towards a defetishised and emancipated social world. Along with numerous individual and collective publications, the richness and diversity of theoretical and political discussions within the Open Marxist discourse were best exemplified by the three-volume work entitled "Open Marxism", which was published between 1992 and 1995. Together with 
Holloway's Change the World without Taking Power (2002/2005) and Bonefeld's Critical Theory and the Critique of Political Economy (2014), they provided the basic outlines for a radical rethinking and re-examination of fundamental Marxian concepts and Marxist categories, rejecting, at the same time, the dogmatism, orthodoxy, determinism and positivism that marked the initial phases in the development of Marxist thought. Open Marxism's critical undertaking was associated with the journals Capital and Class and Common Sense (1987-99). In contrast to Axelos's focus on Marx's early writings, Clarke, Bonefeld, Gunn and Holloway examined Marx's work in its entirety. It can be argued that they uncovered a "young", "new" Marx in the "mature" Marx. Their individual contributions are varied and one must not overlook the disparities in the approaches. And these differences do affect the content of their intellectual trajectory and their critical endeavour. However, there is a discerned common foundation to the work of these authors, which, along with its other shared features, result in Open Marxism's distinctiveness. In his 1987 article entitled "Open Marxism" with which Bonefeld launched the first issue of the journal Common Sense, one can identify the key concepts that determined the future character of what came to be regarded as the CSE Open Marxist school: "crisis", "class struggle", "critique and destruction", "demystification", "openness of categories" and "the principle of doubt". More specifically, the negative character of Open Marxism's critique, that is, their radical rethinking of the meaning of critique not as a normative and constructive, but as negative and destructive critique, has defined the common ground of the Open Marxist tradition from the work of Axelos up to the present day. The following section focuses on the subversive character of their critique, which enables connections and mutual lines of development to form alongside points of individual departure.

\section{DESTRUCTIVE CRITIQUE, NEGATIVITY AND SUBVERSIVE REASON}

Marx and Engels envisaged the radical transformation of capitalist social relations through revolutionary, practical-critical activity by the "proletarian movement", which they regarded as "the self-conscious, independent movement of the immense majority, in the interest of the immense majority" (Marx and Engels, 1991: 44). As such, the creation of this radical movement would rely "solely and exclusively upon the intellectual development of the working class, as it necessarily had to ensue from united action and discussion" (1991: 33). Independent, united action and intellectual growth are the fundamental premises for the 
movement's further quantitative and qualitative improvement. The prerequisites to these premises are freedom of expression and independent critical thinking, which are more needed at moments of danger and defeat, and against the survival of positivism that has over and over again predominated the struggles for human emancipation. This independent, living movement of the people becomes aware of its own essence in the process of class struggle itself. It is in, and through, the unfolding of class struggle that such a movement breaks the continuum of history by the deployment of "courage, humour, cunning and fortitude" (Benjamin, 1969: 255) and never forgets "its hatred and its spirit of sacrifice" (1969: 260). Within the long, continuous and autonomous process of social struggles, subversive cunning and refusal-fuelled by rage and hate-constituted the springboard for an ongoing, penetrating criticism of capitalist relations. Yet, during the course of the twentieth century, a tendency towards theoretical conformity overpowered the various existing dogmatic and mechanistic versions of Marxism, and resulted in a less critical and subversive, and more affirmative, Marxist discourse. In contradistinction to Marx's own critical thinking, traditional Marxism was now reduced to mere "ideology", sterilizing and preserving theory as a codified set of "holy canons". The notion of "orthodoxy" was introduced into the socialist movement, and Marxism turned into a "scientific Weltanschauung", thus becoming a complete(d), and closed, theoretical system. The institutionalization of Marxism reduced it to a reformist and established ideology marked by fatalism, positivism and technicism. The socialist movement transformed from a revolutionary class-struggle movement into a political and social reform movement, and Marxism ceased at this time to develop as a living, and subversive, body of theoretical work. ${ }^{1}$

This transformation, from pro-actively subversive, to fatalistic, entailed the "positivisation" of Marxian thought, in conjunction with the loss of Marxism's radical and critical character, and constituted what Adorno explicitly berated as a "widespread [...] anti-critical spirit [...] in those whose interest should lie in critique" (Adorno, 2005: 286). Demands for "positive", "constructive" and "responsible" critique neutralized the impact of that critique by limiting the terms of its aims and scope from the outset. Marxist tradition and modes of "heretical" thought lost impetus. Appeals to positivity resulted in a debasement of intellectual critical purpose and rendered it "a mere ornament to the material base which it claims to transcend" (Adorno, 1967: 21). Hence, Axelos, in his work, calls for a ceaseless interrogation, questioning and problematizing of Marx's thought in order to make sense of and to overcome the positivisation of critical discourse and the crisis in Marxism. He argues that the crisis is 
unfolding on three levels: on an economic level, at which Marxism has appeared seemingly incapable of resolving or effectively eclipsing the economic problems of capitalism; on a political level, at which Marxism has failed to solve the question of political power and to address it in a radical way - on the contrary, instead of recycling political power, Marxism has recycled revolution, by seizing upon its aftermath as an opportunity to establish new forms of authority - and thirdly, the crisis is obvious on a philosophical level, since Marxism has abandoned radical and questioning thought. On this point, Axelos notes that "Marxism does not place itself in question sufficiently enough and does not ask radical questions" but, rather, it has remained "determined by that which it claimed to negate" (Axelos, 2015a: 148, 149).

One of Axelos's basic assumptions is that Marx's critical confrontation with the thought of Hegel, Smith and Ricardo aimed not to supply us with an improved philosophy of history, or a better and alternative exposition of political economy. Marx's purpose was to introduce "philosophical and historical criticism into philosophy and economy" (1976: 57). In pursuing this end, Marx's critical endeavour points towards "concreteness and freedom from mystification" (1976: 56). Following Axelos's view, Marx introduces us to the "movement of the negativity that runs through universal history" and at the same time, he opens himself "to the future that lies at hand, which, through its negativity will in turn generate what more distantly is yet to come" (1976: 333, 335). For Axelos, Marx's thought encompasses negativity, but this negativity has been blocked, since Marx's original work was systematised into the various Marxisms, and as a result, became reified and objectified itself. In Axelos's understanding, this process sidelined Marx's revolutionary elements and constricted the inherent openness of his theorizing. The problems posed and the questions addressed by Marx did not remain open. On the contrary, the internal contradictions of his thought were pacified and concealed by the reduction of Marxism to an ideology and apologetic doctrine. The freeing of the Marxian thought, according to Axelos, entails the releasing, reactivation and putting into action of its very negativity. It postulates the need to "put the negative to work" (Axelos, 1982: 67), and favours the significance of critical and negative thinking, which is "calling everything in question and keeping the question open" (1982: 67).

Axelos' critique of Marx's early writings, however, remained restricted insofar as it did not take into account Marx's criticism of fetishism, and failed to fully conceive of Marx's critique of political economy and economic categories. He sought to activate and make effective the function of negativity, but he did not elucidate what exactly constitutes this 
movement of negativity. Categories and concepts, such as truth and power, do not derive their value from the social relations in which they occur. Instead, it appears that in Axelos's account their validity derives from the questioning process itself, which is hypostasized and fetishized as an end in itself, while the social relations and social conditions of productions are neutralized (1982: 68). Instead, for critical theory, concepts are socially valid and "even the most abstract categories [...] are valid only in the context of specific relations" (Schmidt, 1981: 36-7). In Axelos's theorising, negativity and questioning thought reveal themselves, in an abstract and ahistorical manner, as being part of the "game-playing" of the world, which in turn constitutes the essence of being. Thus, the meaning of his negative critique is not made explicit. Neither does he explains with clarity the object of his critique, nor his explicit purpose. He persists in his efforts to proceed towards broadening horizons and opening up closed systems, but his stance remains contemplative and his engagement with the material world and social reality, which feature primarily in his writing as references to "technology", is limited, failing thus to achieve "the changing of philosophy into a philosophy of changing the world" (Bloch, 1976: 9) The issue regarding the constitution of the world remains untouched, and Marx's critical undertaking is not understood as a theory of struggle against capitalism. This implies a misunderstanding and disregard of Marx's work as a critique of economic categories, and Axelos's critical approach to Marx unfolds as a philosophical critique. His attempt to read Marx alongside Heidegger left his planned project-a comprehensive critique of philosophy, of political economy and of politics-ultimately underdeveloped, and embedded in the speculative. ${ }^{2}$

In the Open Marxist tradition, Agnoli's work sees Marx's critique of political economy as unfinished project - not only in the sense of an ongoing need for further development of this critique, but also from a perspective that maintains that Marx's thought must be complemented with a critique of the political. Agnoli's critique of the political developed alongside the distinction he drew between "destructive" and "constructive" critique (2003), which has functioned as a touchstone for his critical and subversive work. Akin to Adorno, he argues that the notion of constructive critique acts as a servant of existing powers and state institutions. It enhances trust and confidence to the established order, while, at the same time, seeking to reconcile social contradictions by institutionalizing and integrating any form of radical opposition. Constructive critique encourages responsibility, and contributes to political stability. It endorses the normative values of capitalist society and seeks to improve the existing political system by accepting the rules of parliament. Social and parliamentary 
responsibility has led to the pacification of social conflict and the transformation of the Left. Agnoli's notion of critique amounted not to a critical political science, but to a critique of politics. Though critical political science still provides significant negative material for reflection, it ends up being an endless process of protesting for the humanising, beautifying and reforming of capitalist institutions, without revolt and without any genuine anti-capitalist agenda (Agnoli, 2012c: 197). Opposed to scholarship that produces constructive critique, Agnoli vindicated the meaning of critique as destructive, and a negative undertaking. Destructive critique reaffirms the very essence of critical thought, and has played a vital historical role in "provoking insubordination and destroying horrors" (2003: 26). For Agnoli, the purpose of critique is refusal, negation and subversion — both practical and theoretical —of a world that lacks freedom and equality, a world of capitalist misery. His negative, destructive critique, then, is a negation of all conditions of exploitation, humiliation and coercion. It is a subversive and destructive critique of capital and its state, which challenges existing social relations of domination and finds its positive moment in the creation of different relations, the "society of the free and equal", and not merely in the improvement of existent capitalist power relations. In turbulent and miserable times, as Agnoli argues, a concrete project of emancipation only with the negative potential, - a "subversive science"can effectively co-exist (2012c: 200).

One of the tenets of the strand of Open Marxism that emerged in the early 90s was that "the central category of openness is that of critique" (Bonefeld et al., 1992b: xiii). Expanding on Agnoli's negative critique of the political, and under the influence of Adorno's workespecially his Negative Dialectics-Bonefeld further elaborated the meaning of critique and in doing so advanced both critical theory and the legacy of Adorno. Based on a critical deployment of the "new reading of Marx" (see Bonefeld, 2014), he spelled out the political and social implications of Marx's critique of political economy as a critique of economic categories. Along with Clarke, Holloway and Gunn (with all their differences), Bonefeld maintained that critique is not to be regarded as a means of demonstrating alternative Marxist economic theory, and its superiority to classical political economy (2001: 54). As Simon Clarke has maintained, the term "Marxist political economy" is "a contradiction in terms, since Marx always referred to his work as a "critique of political economy"' (Clarke, 1994: 10). Marx criticized not only bourgeois political economy, but also the very notion of "political economy". Viewed this way, as Holloway noted, Marx's own understanding of the concept of "science" does not imply a search for objectively "correct" knowledge. Rather, it 
amounts to "the movement of criticism", which finds form as a double movement: "an analytical movement and a genetic movement, a movement of going behind appearances and a movement of tracing the origin or genesis of the phenomenon criticised" (Holloway, 2005: 109).

For the Open Marxism thinkers of the CSE, the meaning of critique amounts to a critique of economic categories, one that challenges the unreflected presuppositions of economics. Its scope is to decipher the social constitution of the objectified economic forms and show that economic categories such as money, profit, rent, wage and capital are inverted social relations, which appear as independent self-acting economic forces. The purpose of critique, then, is neither to discover economic laws nor to define social reality by registering and classifying facts. It does not seek to explicate one economic phenomenon with reference to another, but to comprehend each phenomena as a form, or mode of existence of the actual relations of life (Bonefeld, 2014 and 2016). However, whereas for the "new reading of Marx" and for Backhaus in particular, critique is developed from an "anthropological" standpoint with the intention of demystifying economic categories on a human basis (Backhaus, 2005: 28), for Bonefeld the starting point for an ad hominem (see Adorno) critique is "neither economic character nature or anthropology but the 'definite social relations' that manifest themselves in mysterious economy forms" (Bonefeld, 2014:8). Critique questions the outward appearance of economic things, and its objective must be the disclosure of economic categories as social categories, by revealing their "essence"- that is to say, by "deciphering them as human social forms, not of Man as an 'abstract individual', but of Man as a member of a definite form of society" (2014:39). In this respect, for Open Marxism, conceptuality does not mean an application of theory to practice, with a view to analyzing reality from the outside as objective, external observers. The "form analysis" entails a dialectical, internal and reciprocal relationship between theory and practice, where "practice is theory-inclusive just as theory, for its part, is practice related" (Gunn, 1987a: 41). In distinction to Axelos`s abstract negativity, theory and theoretical concepts are held here, then, to be practically reflexive, as they perceive their own validity in their "practical and social constitution" (Gunn, 1987a: 42). As Bonefeld has succinctly put it, "validity is a social category. Only for society can something be valid and have validity" (Bonefeld, 2014: 25).

The concept of "social form" is at the core of the Open Marxist critical tradition. By investigating the social constitution of economic categories, Open Marxism seeks to understand why definite social relations (content) acquire the "forms" (appearance) of state, 
parliament, money, capital and so on. Gunn conceives of social phenomena and structures as "forms", assumed during the processes of class struggle, as "appearances" or "modes of existence", of the contradictory movement of antagonistic social relations and, especially, capital-labour relations (Gunn, 1987b: 60 and Gunn: 1992). Capitalist forms appear, for Open Marxism, as self-established economic entities, which render invisible the constitutive role of human social practice. Actual social relations are reduced to mere by-products of economic forms. The world of economic abstractions and economic categories assert themselves as 'perverted forms' of definite social relations. Relations between individuals appear in their perverted form of economic objectification, in the apparently independent movement of coins and economic forces. These inverted and distorted forms (e.g. state-form, money-form or capital-form), are forms through, and in which, class antagonism subsists - they must be deciphered, therefore, in order to reveal their social origins. According to Bonefeld, "there is only one world, and that is the world of appearances" - that is to say, society as a relation of objectified economic forms - and "this appearance is real" (2016: 63). The world of appearance must be decoded in order to unveil its constitution within social relations. The purpose of negative critique, then, is not to ponder fetishized economic things, but to think "out of these things" (Bonefeld, 2014: 10). Instead of aiming to criticizing the "thing initself", it chooses to interrogate the "definite social relations that express themselves in the form of a relationship between things" (Bonefeld, 2014: 37). In other words, the critique of political economy "thinks out of, and in and through, 'the existent' society. In order to understand things, one has to be within them" (2014:38) Its objective is to discover the social constitution of these reified things, to grasp the social relations that result in the existence of these objectified things, and then disappear by denying themselves in the appearance of economic objectivity.

For Open Marxism, conceptuality does not just mean the process of deciphering the hidden essence of things in human practice. It also involves a process of disclosing their contradictory constitution and movement. At the same time, critique is immanent to its social context, criticizing both the "perverted social existence and the perversion through which it itself exists" (Bonefeld et al., 1995:3). According to Adorno, for negative critique to proceed dialectically would involve thinking "in contradictions, for the sake of the contradiction once experienced in the thing, and against that contradiction" (Adorno, 2003a:133). Open Marxism gives particular emphasis to the concept of contradiction and holds dialectics as "signalling a unity of opposites and movement of contradiction" (Bonefeld et al., 1992b: xiv). In this 
sense, it understands criticism as an "assault on identity" (Holloway, 2005: 106) and argues that if Marxism is a " 'theory of' anything, is a theory of contradiction" (Gunn, 1994: 53). For Gunn and Holloway, in opposition to the various schools of traditional Marxism, Marxism is not regarded as a theory that aims to supply a theory of society and an interpretation of the objective laws of capitalist society. Marxism should not be reduced to a theory of capitalist domination and the study of the function and reproduction of existent structures. Instead, for both these writers, Marxism must reclaim its lost negativity and become a theory against society, a theory that intends the destruction of capitalist society (Gunn, 1992 \& 1994 and Holloway, 1993: 19 \& 2005: 135-6). As a subversive negation of capitalist social relations then, Open Marxism provides a thorough and radical critique of the various perverted social forms, and seeks to reveal the social content, the essence, hidden under the surface of this "topsy-turvy world". Human practice is enslaved, and rendered invisible by the very nature of what it has created and produced. The producers are governed by their own creation, and dominated by abstract economic forces and laws. The creators appear as derivatives of an inverted world, one that acquires an eternal quality by presenting itself as wholly natural, and constitutive of actual social relations.

Revealing the social genesis of a world governed by coins, things and economic abstractions, Open Marxism's negativity amounts primarily to a critique of fetishism, an approach that deciphers and conceptualizes the convenient "forgetting" of societal constitution. The theme of fetishism is central to Open Marxists' critique of capitalistically organized social relations, despite the differences that exist regarding the interpretation of fetishistic categories within this body of work as a whole. For Holloway, the concept of fetishism is at once a "critique of bourgeois society, a critique of bourgeois theory and an explanation of the stability of bourgeois society" (2005: 51) He argues that in the world of capitalist relations, commodities and things rule, and human creativity is rendered invisible. There is an inversion between subject and object, people and things and, as a consequence, social relations are themselves fetishized. Following the critical tradition, Holloway does not consider fetishism as a closed and static concept. According to Horkheimer, "tension characterizes all the concepts of the critical way of thinking [...] the critical acceptance of the categories which rule social life contain simultaneously their condemnation" (Horkheimer 1972: 208). Holloway's work unfolds in a processual, dynamic analysis of the notion of fetishism and makes a distinction between "hard fetishism" and "fetishisation-as-process" (Holloway, 2002a: 29). He 
conceived of fetishism as a process - that is, as fetishisation, the constant struggle between fetishism and anti-fetishism — and as an open, contradictory category. In his words:

\footnotetext{
The concept of alienation, or fetishism, in other words, implies its opposite: not as essential nonalienated 'home' deep in our hearts, but as resistance, refusal, rejection of alienation in our daily practice. It is only on the basis of a concept of anti-alienation or anti-fetishism that we can conceive of alienation or fetishism. If fetishism and anti-fetishism coexist, then it can only be as antagonistic processes. Fetishism is a process of fetishisation, a process of separating subject and object, always in antagonism to the opposing movement of anti-fetishisation, the struggle to reunite subject and object (2002a: 31).
}

From Clarke's point of view (2002), Holloway uses Marx's vocabulary from Economic and Philosophical Manuscripts of 1844 in his interpretation of Capital. Alienation is not the same as fetishism, and Holloway, in his analysis, seems not to distinguish between the terms reification, alienation and fetishism. Rather, he uses the three terms synonymously. As Holloway has argued, "although people are, in their species characteristic, practical creative beings, they exist under capitalism as objects, as dehumanised, as deprived of their subjectivity" (2002a: 29). In Clarke's view, Holloway "bases his rejection of capitalism not on a critique of capitalist exploitation but on a romantic aspiration to reclaim creativity from capitalist labour" (2002: 41). In his reply to Clarke, Holloway maintains that Marx's early and mature writings are equally concerned with the dehumanisation and objectification of people under capitalism: “The young Marx speaks of 'alienation', the older Marx speaks of fetishism, but both concepts refer to the same objectification of the subject" (Holloway, 2002b: 62). On the other hand, Bonefeld holds that the ad hominem critique of the fetishism of the commodity form does not amount to a "fuzzy humanism", but rather focuses on the "actual social relations of a definite form of society" (2014: 39). As he has argued: "Man is always objectified Man. Subjectivity means objectification. To be an object is part of the meaning of subjectivity. The issue that the critique of fetishism brings to the fore is not the subject's objectification but its reified mode" (2014: 63). In this line of thought, Bonefeld expresses his view that "the fetishism of commodities does not disguise the 'real' social relations of capitalism. Rather, the fetishism of commodities expresses the 'real' social relations in the form of capital as the automatic subject of bourgeois society" (2014: 54).

\section{THE CRITIQUE OF POLITICAL ECONOMY AS A CRITICAL SOCIAL THEORY: ON CLASS AND STRUGGLE}


The fetishism of commodities amounts to a process in which capitalist social relations manifest themselves as being abstract economic forces. The "new reading of Marx" has made a valuable contribution to the task of unpacking the "natural" appearance of economic objectivity and in showing the ways in which social relations are inverted, and reshaped into reified economic forms that assume a mantle of inevitability, and of necessity. Yet, according to Bonefeld, the "new reading of Marx" does not "explain the social character of economic objectivity"; after all, "What is objectified?" (Bonefeld, 2014: 10). Because it did not seek to expound the "fundamental categories" of "class and labour" (2014: 41, 42), the critical work of the "new reading of Marx" was incomplete. Elaborating upon the critique of economic categories as a critical theory of social constitution, the CSE Open Marxist school "substitutes the critique of the actual social relations for a logical development of the value form as some secularized thing that is valid in-itself" and builds upon a "critical theory of abstract labour, class and class antagonism" (2014: 42). Open Marxism theorists developed the critique of political economy into a critical social theory of economic objectivity, one that includes not only critique of economic form but also of the political form of a society. A key aspect of this critique is its refutation of positivistic and "scientific" pretentions, which it finds within the various strands of traditional Marxism. During the radical debates conducted by the Conference of Socialist Economists (e.g. see Clarke, 1991a), Open Marxism's ideas flourished-and this theoretical-critical activity was never conducted in isolation from political questions and concerns. Most importantly, these scholars' critical analyses centred on the determining role of class struggle, as they saw that a purely logical exposition of economic categories dismisses the relationship between capital and labour, and class antagonism from critique of political economy. Arguing against traditional Marxist theories, which proposed the notion of a "Marxist economics", Holloway notes that they conceive of economic categories, such as value, price, crisis and so on, "as having an objective validity which does not depend on class struggle" (Holloway, 1995: 161). For the CSE Open Marxism school, the deciphering of the social basis of economic categories reveals that these relations are contradictory and antagonistic and that, therefore, class struggle acts as a constitutive precondition of objectified economic forms.

By addressing the issue of economic objectivity and its class character, Open Marxism views class struggle as the content of concepts, as the constitutive essence concealed within economic and political categories. Social individuals become invisible in the movement of economic quantities and, as a consequence, class relations disappear in the exchange of 
economic things. Therefore, the notion of class cannot be adequately conceptualized at the mere, basic level of appearances and levels of reliance upon revenue sources as means of classifying people into the various social classes. Marx's critique of the "Trinity Formula" (capital-profit, land-rent, labour-wage) involves a rupture with the world of appearances and the conceptualization of class as a group of people, or a structure. According to Clarke, a class "is not an interest group, defined as a coalescence of individuals with a common interest, but is an inseparable part of a relation of production and as such is analytically prior to the individuals who comprise it" (1978: 41). Class relations are the "logical and historical presupposition of capitalist production" (Clarke, 1991b: 118), that is to say, a precondition of the specific relations of domination and exploitation that unfold between the capitalist and the workers in the realm of production. In his critique of Althusserian Marxism, Clarke has argued that class in not a "thing" but a definite social production relation, and that class relations between capital and labour acquire specific economic, ideological and political forms, which are "historically developed forms of the relations of production" (Clarke, 1980:53). They constitute a contradictory unity of diverse and specific forms of social relationships. As such, class relations, which are grounded in the extraction of surplus value occurring in the production process, "are not purely 'economic' but are, in class societies, multidimensional power relations which are expressed in particular ideological forms" (1980: $53)$.

In an influential article, Gunn also argues against a traditional and "sociological" conception of class. Class is neither a group of individuals classified together according to their common socio-economic trait, nor a "place", that is, a "structure" in which individuals are located in relation to the fixed position they occupy within the social landscape. For Gunn, the terms "class" and "class relation" must be understood as undifferentiated - as class is always a "class relation of some historically particular kind" (Gunn, 1987c: 15). Further, he sees class relations as the aggregate of social relations, which must be understood as production relations. In other words, the antagonism between capital and labour is not merely an economic, but a social relationship. Within these social relations, the classes do not confront each other as pre-established entities and structurally pre-determined categories. In an active, dynamic and unpredictable process, class struggle defines and constitutes the formation of class. Developing his argument, Gunn maintains that class is a relation of struggle, and therefore, "class struggle is class itself" (1987c: 16). Being an antagonistic struggle, class relation, that is, the capital-labour relation, does not seek to fit people into groups or 
pigeonholes. As a fluid relationship, it is independent of individuals, yet also constructs their lives, as it subsists in and through them. In short, it permeates their lives. As Gunn puts it, class relations structure the "lives of different individuals in different ways. It allows the line of class division to fall through, and not merely between, the individuals concerned" (1987c: 17). Running through individuals, fragment individuals` lives and as a result, their existence, in the individual and collective senses, becomes contradictory. Being contradictory, class divides and fragments members of the working class, whose "feet remain mired in exploitation even while his or her head [...] breathes in bourgeois ideological clouds" (1987c: 17). In many different ways, Gunn's contribution offers a number of insightful and intriguing comments, but failed to adequately set out the theoretical and political implications of his approach. What is of particular note is his attempt to argue against traditional Marxist class analyses, which viewed class as an "object" and conceptualized class and class struggle in a rather instrumentalist manner. From that perspective, by breaking with traditional and positivist interpretations of classes as "social groups", he offered a critical conception of class and class struggle, thereby opening up space for a more in-depth treatment of the subject informed by negative dialectics. Besides, as Tischler has put it, "if class is viewed as an object, then revolutionary dialectics as negative dialectics cannot exist” (2002:178).

Extending Gunn's perspective and building on Adorno's own critical theory, Bonefeld aims at offering a critique, and not a theory, of class. From the standpoint of critical theory, Bonefeld argues that "class is not primarily a category of consciousness. It is a category of a perverse form of social objectification" (2014: 114). As he succinctly put it, "Marx`s critique of political economy does not derive the existence of classes from class-consciousness. He analyses the manner in which society organizes its social reproduction" (2014:117). For Bonefeld, social theory is critical when it makes sense of society from a starting point of recognising its social constitution, thus investigating society from within its mode of subsistence and from the standpoint of struggle and contradiction. From this vantage point, he has pointed out that "class is not an affirmative category, but a critical concept" (2002a:66). Capitalist society is fundamentally antagonistic and torn by contradictions. Adorno pointed out that society is reproducing itself because of its contradictions and opposing interests. Mankind survives and "preserves itself not despite all irrationalities and conflicts, but by virtue of them" (Adorno, 2006: 50). The antagonistic class relationship between the rulers and the ruled, between capital and labour, reproduces the system and assists it in extending itself as "society stays alive, not despite its antagonism, but by means of it" (Adorno, 2003a: 
320). In this struggle between antagonistic forces, opposing individuals act as personifications of specific and definite class relations and class interests. In this process, to exist as a seller of labour power and to "be a productive labourer is not an ontologically privileged position" (Bonefeld, 2016: 69). As Marx argues, and Bonefeld frequently reminds us, "to be a productive worker is therefore not a piece of luck, but a misfortune" (Marx, 1990: 644). As a negative and critical concept, then, class is part of a reified society and belongs to a perverted world of social relations, being an "objective category of the false society" (2014: 100). As part of the perverted appearance of social relations, class is experienced as a "living contradiction. Contradictions cannot be classified" (2014: 107). Struggling in and through this contradiction, labourers share a common class experience, that is, their separation from the means of production and the compulsive selling of their labour power, which creates the conditions for "class unity and collective action" (2014: 114). On the other hand, as Bonefeld forcefully remarks, economic compulsion denotes the "common class experience of labour market disunity, as each individual seller of labour power competes against the other for employment as the condition of gaining access to the means of life" (2014: 115).

On this, Holloway argues that "we do not struggle as working class, we struggle against being working class, against being classified" (Holloway, 2002a: 36). Holloway, viewing attempts to define the working class as subordinated to capital, as part of the traditional "understanding" of the working class, considers class as process, as a dynamic concept. In this line of thought, classes are not pre-constituted, fixed, static entities. Their existence cannot be separated from their constitution. Rather, classes are in a constant process of being constituted, as people are subjected to an unceasing process of classification and reclassification. This in turn entails that class struggle "is the struggle to classify, and against being classified" (2005: 143). In this struggle, the working class battles against labour and against being working class, in order to emancipate itself. In this respect, according to Holloway, the working class "can be considered revolutionary only to the extent that it exists not only in but also against-and-beyond itself as working class" (Holloway, 2010: 118). Holloway surmises that class struggle is unfolding within capitalist society, and at the same is moving forward in a direction that leads beyond this society. The issue at stake, as Bonefeld notes, is "what this 'beyond' might be. The class struggle for subsistence does not foretell the future. It does however entail a profound judgment on the existing relations of social wealth" (2014: 118). 
Class struggle constitutes part of the rationalized irrationality of the capitalist reality as long as it continues to feature within the framework established by the Trinity Formula, principally seeking, merely, to ameliorate exploitation within the labour process. This struggle can be viewed as one that operates inside the perimeters of the perverted capitalist social reality, from where it satisfies itself with demands for a "just" wage and trade union recognition; such struggles implicitly accept the reality and structures of capitalist society and assist in the continuing reproduction of the 'cold inhumanity of free wage labor' (Adorno, 2003b: 94), driving society into a situation of 'permanent transition or unchanging change' (Adorno, 1961:45). Integrated class struggles perform a reproductive and stabilizing function within capitalism, and in that sense, as Adorno put it, 'all history is the history of class struggle because it was always the same thing, namely, prehistory' (2003b: 94). At issue, then, for Open Marxism is how to end the prehistory of class struggle and how to present Communism as a movement, constructed from a synthesis of previous political and critical experiences and struggles, which fights for a classless society of the 'free and equal' rather than for a rationally organised socialist economy of labour (Bonefeld, 2015:7-10). The unfolding of the Open Marxist tradition, in a continuing critical dialogue, develops questions inherited from the early Frankfurt School, and advances critical social theory as a result. From this perspective, Marcuse's argument gains a new significance:

\begin{abstract}
All development of the productive forces by the established society would perpetuate and increase the productivity of destruction and repression, and that this fatal link could be broken only by the praxis of a class whose vital need was, not the perpetuation and amelioration but the abolition of the established society. And this abolition would be liberation: freedom appears first as negation; the 'positive' definition remains an $\mathrm{X}$, an open variable - just: selfdetermination. (Marcuse, 1972: 214)
\end{abstract}

\title{
NOTES
}

${ }^{1}$ For critical discussions of traditional and worldview Marxism see Bonefeld and Tischler, 2002b and Holloway, 2005.

${ }^{2}$ It is in the work of Karel Kosik that we see Axelos's original aims undertaken with critical rigour and executed with vehemence, although Kosik's legacy resides in undeserved obscurity. Kosik's Dialectics of the Concrete represents the finest example of his critical interpretation of Marx and his combined reading of phenomenology and Marxism. Kosik argued that "Marx's Capital is not a theory but a theoretical critique or a critical theory of 
capital" (1976: 112) and maintained that economics and economic categories cannot be properly comprehended without addressing and replying to the basic question: "how is social reality formed"? (1976: 117). "Marx's theory", Kosik asserted, "is a critique of economics" and this critique "exhibits the real movement of economic categories as a reified form of the social movement of people" (1976: 115). According to Kosik, the economic world appears as a collection of natural, self-evident and autonomous phenomena, which constitute the world of the pseudoconcrete. Economic categories, then, must be grasped as "phenomenal forms" (1976: 108), "forms of being" or "existential determinants" (1976: 114), which conceal the essence of things: the structure and the material reality of existence, and the world of human praxis. In the pseudoconcrete world of economic categories, the distinction between phenomenon and essence disappears. A dialectical theory of society needs, therefore, to demystify and deconstruct the pseudoconcrete and its apparent independence, in order to render essence perceptible. Such a theory must seek to reach the concrete and to demonstrate economic categories as derivative and mediated phenomena of social praxis and human social relations, organized in an historically specific and concrete manner. "Economics", Kosik opined, "is the objective world of people and of their social products; it is not the objectual world of the social movement of things" (1976: 115).

\section{REFERENCES}

Adorno, Theodor (1961) " "Static" and "Dynamic" as sociological Categories', Diogenes, 9: $28-49$.

Adorno, Theodor (1967) 'Cultural Criticism and Society', in T. Adorno, Prisms. Cambridge, Massachusetts: The MIT Press. pp. 19-34.

Adorno, Theodor (1997[1962]) 'Seminar Mitschrift von 1962', Appendix to H. G. Backhaus, Dialektik der Wertform . Freiburg: Ça Ira, pp.501-13.

Adorno, Theodor (2003a) Negative Dialectics. London: Continuum.

Adorno, Theodor (2003b) 'Reflections on Class Theory', in R. Tiedemann (ed.), Can one live after Auschwitz? Stanford, California: Stanford University Press, pp. 93-110.

Adorno, Theodor (2005) 'Critique' in T. Adorno Critical Models. New York: Columbia University Press. pp. 281-288. 
Adorno, Theodor (2006) History and Freedom. Cambridge: Polity Press.

Agnoli, Johannes and Mandel, Ernest (1980) Offener Marxismus: Ein Gespräch über Dogmen, Orthodoxie und die Häresie der Realität. Frankfurt: Campus.

Agnoli, Johannes (2003) 'Destruction as the determination of the scholar in miserable times', in W. Bonefeld (ed.), Revolutionary Writing. New York: Autonomedia, pp. 25-37.

Agnoli, Johannes (2012a) 'Der Markt, der Staat und das Ende der Geschichte' in Agnoli, Johannes, Die Transformation der Demokratie und verwandte Schriften. Hamburg: Verlag, pp. 203-211.

Agnoli, Johannes (2012b) 'Zwanzig Jahre danach' in Agnoli, Johannes, Die Transformation der Demokratie und verwandte Schriften, Hamburg: Verlag, pp. 137-192.

Agnoli, Johannes (2012c) 'Von der kritischen Politologie zur Kritik der Politik' in J. Agnoli, Die Transformation der Demokratie und verwandte Schriften, Hamburg: Verlag, pp. 193202.

Arato, Andrew and Gebhardt, Eike (ed.) (2007) The Essential Frankfurt School Reader. New York : Continuum.

Axelos, Kostas (1957) 'Marxisme ouvert ou Marxisme en marche ? Arguments, (5) : 17-20.

Axelos, Kostas (1966) Einführung in ein künftiges Denken: Über Marx und Heidegger, Tübingen: Max Niemeyer Verlag Tübingen.

Axelos, Kostas (1970) 'Marx, Freud, and the Undertakings of Thought in the Future', Diogenes, 18, 72: 96-111.

Axelos, Kostas (1976) Alienation, Praxis and Techne in the Thought of Karl Marx. Austin: University of Texas Press.

Axelos, Kostas (1982) 'Theses on Marx', in N. Fischer, L. Patsouras, N. Georgopoulos (ed.) Continuity and Change in Marxism. New Jersey: Humanities Press.

Axelos, Kostas (2015a) 'Twelve Fragmentary Propositions Concerning the issue of Revolutionary Praxis', in K. Axelos, An Introduction to future Ways of Thought: On Marx and Heidegger, edited by Stuart Elden, Lüneberg: Meson Press. pp. 147-151.

Axelos, Kostas (2015b) 'Foreword' in K. Axelos, An Introduction to future Ways of Thought: On Marc and Heidegger, edited by Stuart Elden, Lüneberg: Meson Press, pp. 37-9.

Backhaus, H. G. (2005) 'Some Aspects of Marx's Concept of Critique in the Context of his EconomicPhilosophical Theory' in W. Bonefeld and K. Psychopedis (ed.) Human Dignity: Social Autonomy and the Critique of Capitalism. Aldershot: Ashgate.

Benjamin, Walter (1969) 'Theses on the Philosophy of History', in Hannah Arendt (ed.), Illuminations. New York: Schocken Books. pp. 253-264. 
Bloch, Ernst (1976) 'Dialectics and Hope', New German Critique, 9: 3-10.

Bonefeld, Werner (1987) ‘Open Marxism’, Common Sense, 1: 34-38.

Bonefeld, Werner (1992a) 'Constitutional Norm versus Constitutional Reality in Germany', Capital \& Class, 46 (1): 65-88.

Bonefeld, W. Gunn, R. and Psychopedis, K. (1992b) (ed.) Open Marxism: Dialectics and History, vol. 1. London: Pluto Press.

Bonefeld, W. Gunn, R. and Psychopedis, K. (1992c) (ed.) Open Marxism: Theory and Practice, vol. 2. London: Pluto Press.

Bonefeld, W. Gunn, R. Holloway. J. and Psychopedis, K. (1995) (ed.) Open Marxism: Emancipating Marx, vol. 3. London: Pluto Press.

Bonefeld, Werner (2001) 'Kapital and its Subtitle: A Note on the Meaning of Critique', Capital \&Class, 75: 53-63.

Bonefeld, Werner (2002a) 'Capital, Labour and Primitive Accumulation: On Class and Constitution' in A. Dinerstein and M. Neary (ed.) The Labour Debate. Aldershot: Ashgate. pp. 65-88.

Bonefeld, Werner and Tischler, Sergio (ed.) (2002b) What is to be Done? Leninism, Anti-Leninist Marxism and the question of revolution today. Aldershot: Ashgate.

Bonefeld, Werner (2014) Critical Theory and the Critique of Political Economy. London: Bloomsbury.

Bonefeld, Werner (2015) 'Bringing critical theory back in at a time of misery: Three beginnings without conclusion’, Capital \& Class, pp. 1-12.

Bonefeld, Werner (2016) 'Negative Dialectics and the Critique of Economic Objectivity', History of the Human Sciences, 29(2): 60-76.

Clarke, Simon (1978) 'Capital, Fractions of Capital and the State: 'Neo-Marxist' Analysis of the South African State’, Capital \& Class, pp. 32-77.

Clarke, Simon (1980) 'Althusserian Marxism', in S. Clarke, T. Lovell, K. McDonnell, K. Robins and V. Seidler (ed.) One-Dimensional Marxism. London: Allison \& Busby. pp. 7-102.

Clarke, Simon (ed.) (1991a) The State Debate. London: Palgrave.

Clarke, Simon (1991b) Marx, Marginalism and Modern Sociology. London: Palgrave.

Clarke, Simon (1994) Marx`s Theory of Crisis. London: Macmillan.

Clarke, Simon (2002) 'Class Struggle and the Working Class: The Problem of Commodity Fetishism' in A. Dinerstein and M. Neary (ed.) The Labour Debate. Aldershot: Ashgate. 
Elden, Stuart (2005) 'Mondialisation without the World', Radical Philosophy, 130: 25-28.

Gunn, Richard (1987a) 'Practical Reflexivity in Marx', Common Sense, no 1: 39-51.

Gunn, Richard (1987b) ‘Marxism and Mediation', Common Sense, no 2: 57-66.

Gunn, Richard (1987c) 'Notes on Class', Common Sense, no 2: 15-25.

Gunn, Richard (1992) 'Against Historical Materialism: Marxism as First-Order Discourse', in W. Bonefeld, R. Gunn, and K. Psychopedis, (1992c) (ed.) Open Marxism: Theory and Practice, vol. 2. London: Pluto Press, pp. 1-45.

Gunn, Richard (1994) ‘Marxism and Contradiction', Common Sense, 15: 53-58.

Holloway, John (1993) 'The Freeing of Marx', Common Sense, 14: 17-21.

Holloway, John (1995) 'From Scream of Refusal to Scream of Power: The Centrality of Work' in W. Bonefeld, R. Gunn, J. Holloway. J. and K. Psychopedis (ed.) Open Marxism: Emancipating Marx, vol. 3. London: Pluto Press. pp. 155-181.

Holloway, John (2002a) 'Class and Classification: Against, In and beyond Labour' in A. Dinerstein and M. Neary (ed.) The Labour Debate. Aldershot: Ashgate.

Holloway, John (2002b) 'The Narrowing of Marxism: A Comment on Simon Clarke`s Comments' in A. Dinerstein and M. Neary (ed.) The Labour Debate. Aldershot: Ashgate.

Holloway, John (2005) Change the World Without Taking Power. London: Pluto.

Holloway, John (2010) Crack Capitalism. London: Pluto.

Horkheimer, Max. (1972) 'Traditional and Critical Theory', in M. Horkheimer Critical Theory: Selected Essays. New York: Herder and Herder.

Horkheimer, Max (2007) 'The Authoritarian State', in A. Arato and E. Gebhardt (ed.) The Essential Frankfurt School Reader. New York: Continuum. pp. 95-117.

Kosik, Karel (1976) Dialectics of the Concrete. Boston: D. Reidel Publishing Company.

Marcuse, Herbert (1972) 'Freedom and the Historical Imperative', in H. Marcuse Studies in Critical Philosophy, London: NLB, pp. 209-223.

Marx, Karl (1990) Capital, Vol. I. Harmondsworth: Penguin.

Memos, Christos (2009) 'For Marx and Marxism: An Interview with Kostas Axelos', Thesis Eleven, 98:129-39.

Paz, Octavio (1991) Piedra de Sol (Sunstone), translated by Eliot Weinberger. New York: New Directions. 
Poster, Mark (1975) Existential Marxism in Postwar France: From Sartre to Althusser.

Princeton: Princeton University Press.

Schmidt, Alfred (1981) History and Structure. Cambridge, MA: MIT Press.

Tischler, Sergio (2002) 'The Crisis of the Leninist Subject and the Zapatista Circumstance' in W. Bonefeld and S. Tischler (ed.) What is to be Done? Leninism, Anti-Leninist Marxism and the question of revolution today. Aldershot: Ashgate. pp. 168-184. 